\title{
PENGEMBANGAN APLIKASI PEMBELAJARAN AKSARA JAWA (AMBARAWA) UNTUK MENINGKATKAN HASIL BELAJAR SISWA SEKOLAH DASAR
}

\author{
Hendri Leo Pradana, Henny Dewi Koeswanti \\ Program Studi Pendidikan Guru Sekolah Dasar Universitas Kristen Satya Wacana \\ Corresponding Author. Email: hendrileopradanaı@@gmail.com
}

\begin{abstract}
This research aims to develop a viable Android-based learning media to improve the learning outcomes of Javanese elementary school students.This research uses ADDIE development model (Analyse, Design, Develop, Implement, and Evaluate).Data collection techniques from this research consist of observation, interview, and validation.Data analysis techniques in the form of descriptive statistics analysis obtained from the validation results of media experts and material experts. The validity of The Java Script Learning Application (AMBARAWA) shows a material validity percentage of $88 \%$ with a very high category and a media validity percentage of $90 \%$ also with a very high category.In conclusion, The Javanese Literacy Learning Application deserves to be used to improve the learning outcomes of Javanese in elementary school students.
\end{abstract}

Keywords:

Learning Media, Android, Javanese.

\begin{abstract}
Abstrak
Penelitian ini bertujuan untuk mengembangkan media pembelajaran berbasis Android yang layak untuk meningkatkan hasil belajar Bahasa Jawa siswa sekolah dasar. Penelitian ini menggunakan model pengembangan ADDIE (Analyse, Design, Develop, Implement, and Evaluate). Teknik pengumpulan data dari penelitian ini terdiri dari observasi, wawancara, dan validasi. Adapun teknik analisis data berupa analisis deskriptif statistik yang diperoleh dari hasil validasi ahli media dan ahli materi. Hasil validitas Aplikasi Pembelajaran Aksara Jawa (AMBARAWA) menunjukkan persentase validitas materi sebesar 88 $\%$ dengan kategori sangat tinggi dan persentase validitas media sebesar $90 \%$ juga dengan kategori sangat tinggi. Kesimpulannya, Aplikasi Pembelajaran Aksara Jawa layak digunakan untuk meningkatkan hasil belajar Bahasa Jawa siswa sekolah dasar.
\end{abstract}

Kata Kunci:

Media Pembelajaran, Android, Bahasa Jawa.

\section{A. PENDAHULUAN}

Indonesia merupakan negara yang memiliki kebudayaan paling beragam di dunia, salah satunya adalah bahasa. Dikutip dari World Economic Forum, Ethnologue: Based on Ethnologue's 2016 rankings, Indonesia menempati peringkat 2 dengan keberagaman bahasa sebanyak 707 dibawah Papua Nugini yang berada pada peringkat 1 dengan keberagaman bahasa sebanyak 839. Berdasarkan catatan Badan Pengembangan dan Pembinaan Bahasa Kementerian Pendidikan dan
Kebudayaan Republik Indonesia, terdapat 718 bahasa Ibu yang telah teridentifikasi. Bahasa Ibu merupakan bahasa yang pertama kali diperoleh oleh individu dan menjadi bahasa komunikasi di lingkungannya (Kemendikbud RI, 2016).

Berdasarkan Undang-Undang Dasar Republik Indonesia 1945 pasal 36 tentang Bendera, Bahasa, dan Lambang Negara, serta Lagu Kebangsaan disebutkan bahwa pengembangan dan pembinaan bahasa negara diserahkan kepada pemerintah pusat, atau dalam 
hal ini adalah Kementerian Pendidikan dan Kebudayaan Republik Indonesia yang disingkat Kemendikbud RI. Sedangkan pengembangan dan pembinaan bahasa daerah diserahkan kepada pemerintah daerah masingmasing, dalam hal ini Dinas Pendidikan dan Kebudayaan Kota, Kabupaten, atau Provinsi. Dalam hal upaya untuk melaksanakan pengembangan dan pembinaan bahasa daerah, Pemerintah Provinsi Jawa tengah telah mengeluarkan Peraturan Daerah (Perda) Jawa Tengah (Jateng) Nomor 9 Tahun 2012 tentang Bahasa, Sastra dan Aksara Jawa. Peraturan tersebut diperjelas melalui Peraturan Gubernur (Pergub) Jawa Tengah (Jateng) Nomor 57 Tahun 2013 tentang Petunjuk Pelaksanaan dari Perda Jateng Nomor 9 Tahun 2012.

Dasar-dasar di atas kemudian menjadi perhatian bagi sekolah formal dalam lingkup Dinas Pendidikan dan Kebudayaan Provinsi Jawa Tengah. Mengacu pada Pergub Jateng Nomor 57 Tahun 2013 pasal 5, Pembinaan Bahasa, Sastra dan Aksara Jawa dilaksanakan di satuan pendidikan formal pada Sekolah Dasar (SD)/sederajat, Sekolah Menengah Pertama (SMP)/sederajat, Sekolah Menengah Atas (SMA)/ Sekolah Menengah Kejuruan (SMK)/sederajat. Artinya, Bahasa Jawa menjadi muatan lokal yang wajib diselenggarakan sebagai mata pelajaran di sekolah formal jenjang Sekolah Dasar sampai dengan Sekolah Menengah, hal ini diperjelas kembali dalam Pergub Jateng No. 57 Tahun 2012 pasal 13.

Sesuai dengan dasar di atas, sudah jelas bahwa bahasa, sastra, dan aksara Jawa wajib dilaksanakan oleh semua satuan pendidikan dalam bentuk mata pelajaran Bahasa Jawa, tidak terkecuali di jenjang sekolah dasar. Sekolah dasar menjadi satuan pendidikan pertama yang wajib melaksanakan pelajaran Bahasa Jawa, salah satunya Aksara Jawa. Berdasarkan pengamatan pelaksanaan pembelajaran Aksara Jawa yang dilakukan melalui wawancara dan observasi di salah satu satuan pendidikan jenjang sekolah dasar, ditemukan bahwa (1) pelaksanaan pembelajaran Aksara Jawa hanya 2 JP (Jam Pelajaran) atau setara 70 menit setiap minggunya, karena kurang dalam halnya alokasi waktu, sehingga tidak seluruh kompetensi tercapai dengan optimal dan maksimal. (2) Media pembelajaran yang digunakan masih berupa tabel aksara Jawa dan Buku Pepak Basa Jawa. (3) Kurangnya pemanfaatan TIK sebagai pendukung proses pembelajaran pada satuan pendidikan jenjang sekolah dasar. (4) hasil belajar siswa dalam mata pelajaran Bahasa Jawa terkhusus materi Aksara Jawa masih kurang.

Imam Abdillah (2014: 43) mengemukakan bahwa bahan ajar atau materi pembelajaran akan menjadi lebih menarik bila disajikan dalam bentuk multimedia. Multimedia saat ini berkembang semakin baik dan pesat dengan dukungan berupa grafis seperti warna, bidang, bentuk, komposisi, dan interaktifitas atau link serta dengan bahasa pemrograman. Dukungan grafis disajikan dalam bentuk penyampaian informasi berupa teks, gambar/grafik, audio/suara, video, dan animasi (gambar bergerak) sehingga menjadi lebih interaktif bagi pengguna (Rika Damayanti dan Mawardi (2017:4)).

Dari data di atas, maka perlu adanya beberapa hal yang perlu dilakukan sebagai upaya membantu menyelesaikan masalah yang terjadi. Hal ini relevan dengan penelitian yang dilakukan oleh Rizki Suhendar Putra, Nanik Wijayati, dan Widhi Mahatmanti (2017: 2009) yang berjudul "Pengaruh 
Penggunaan Media Pembelajaran Berbasis Aplikasi Android Terhadap Hasil Belajar Siswa”, dinyatakan bahwa media pembelajaran berpengaruh dalam meningkatkan hasil belajar siswa. Rahadi (2014: 662), mengemukakan bahwa Android merupakan suatu system operasi yang dirancang untuk keperluan perangkat seluler layar sentuh (touchscreen) seperti halnya smartphone dan tablet. Android merupakan system siap pakai untuk keperluan sehari-hari melalui smartphone yang mudah untuk digunakan (Yuliandi Kusuma, 2011: 12) Selain itu, penelitian yang dilakukan oleh Fina Ulinnuha Arifin Febrianti, Farid Ahmadi, dan Florentina Widihastrini (2018: 1) dengan judul "Pengembangan Game Mobile Media Aksara Jawa Untuk Meningkatkan Hasil Belajar Bahasa Jawa", disimpulkan bahwa media pembelajaran berpengaruh dalam meningkatkan hasil belajar Bahasa Jawa.

Secara umum, masalah di atas dapat diselesaikan dengan penggunaan perangkat pembelajaran yang sesuai, salah satunya adalah media pembelajaran. Menurut Rohani (2019: 7), media pembelajaran merupakan segala sesuatu yang dapat digunakan sebagai pengantar pesan, dapat merangsang pikiran, perasaan, dan kemauan siswa sehingga mampu mendorong proses kegiatan belajar dan mengajar dalam diri siswa serta guru. Dengan kata lain, media pembelajaran berupa alat penyalur pesan/informasi untuk melaksanakan proses pembelajaran. Adapun penelitian ini bertujuan untuk mengembangkan media pembelajaran dalam bentuk Aplikasi Pembelajaran Aksara Jawa atau disingkat AMBARAWA.

\section{B. METODE PENELITIAN}

Penelitian ini dilaksanakan dengan menggunakan jenis Research and Development (RED) dengan menerapkan model pengembangan ADDIE (Analyse, Design, Develop, Implement, and Evaluate). Prosedur yang digunakan dalam penelitian dan pengembangan ini adalah prosedur yang dikembangkan oleh Sukmadinata (2016: 164) yang dapat dilihat pada gambar 1 dibawah ini:

Tabel 1. Tahapan Penelitian dan Pengembangan

\begin{tabular}{|c|c|c|c|c|}
\hline $\begin{array}{l}\text { Tahpan } \\
\text { Penelitian }\end{array}$ & Tujuan & Instrumen & $\begin{array}{l}\text { Sumber } \\
\text { Data }\end{array}$ & $\begin{array}{l}\text { Teknik } \\
\text { Pengolaha } \\
\text { n Data }\end{array}$ \\
\hline 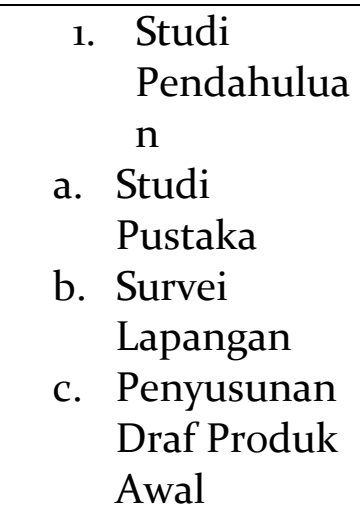 & $\begin{array}{l}\text { Mendeskripsika } \\
\text { n media } \\
\text { pembelajaran } \\
\text { AMBARAWA } \\
\text { untuk } \\
\text { meningkatkan } \\
\text { hasil belajar } \\
\text { siswa sekolah } \\
\text { dasar. }\end{array}$ & $\begin{array}{l}\text { Observasi, } \\
\text { wawancara, } \\
\text { angket, dan } \\
\text { studi } \\
\text { dokumente } \\
\text { r. }\end{array}$ & $\begin{array}{l}\text { Guru dan } \\
\text { siswa SDN } \\
\text { Dukuh o5 } \\
\text { Kota Salatiga }\end{array}$ & $\begin{array}{l}\text { Analisis } \\
\text { data } \\
\text { deskriptif } \\
\text { kategoris }\end{array}$ \\
\hline $\begin{array}{l}\text { 2. Pengemban } \\
\text { gan Produk }\end{array}$ & $\begin{array}{l}\text { Mengembangka } \\
\mathrm{n} \text { produk awal } \\
\text { media }\end{array}$ & & & \\
\hline
\end{tabular}




\begin{tabular}{|c|c|c|c|c|}
\hline & $\begin{array}{l}\text { pembelajaran } \\
\text { AMBARAWA } \\
\text { untuk } \\
\text { meningkatkan } \\
\text { hasil belajar } \\
\text { siswa sekolah } \\
\text { dasar }\end{array}$ & & & \\
\hline $\begin{array}{l}\text { a. Uji Validasi } \\
\text { Ahli }\end{array}$ & $\begin{array}{l}\text { Menyempurnak } \\
\text { an dan } \\
\text { memperoleh } \\
\text { validasi media } \\
\text { serta } \\
\text { mengetahui } \\
\text { kelebihan dan } \\
\text { kekurangan } \\
\text { secara } \\
\text { konseptual } \\
\text { menurut ahli }\end{array}$ & $\begin{array}{l}\text { Rubrik } \\
\text { penilaian } \\
\text { ahli }\end{array}$ & $\begin{array}{l}\text { 3 orang ahli } \\
\text { 1) } 1 \text { ahli } \\
\text { materi } \\
\text { 2) } 2 \text { ahli } \\
\\
\text { media }\end{array}$ & $\begin{array}{l}\text { Analisis } \\
\text { data } \\
\text { deskriptif, } \\
\text { kategori, } \\
\text { dan } \\
\text { presentase. }\end{array}$ \\
\hline $\begin{array}{l}\text { b. Uji Coba } \\
\text { Terbatas }\end{array}$ & & $\begin{array}{l}\text { observasi, } \\
\text { wawancara } \\
\text { pretest, dan } \\
\text { posttest. }\end{array}$ & $\begin{array}{l}\text { Siswa } \\
\text { sekolah } \\
\text { dasar di } \\
\text { sekitar } \\
\text { tempat } \\
\text { tinggal } \\
\text { peneliti. }\end{array}$ & $\begin{array}{l}\text { Analisis data } \\
\text { deskriptif } \\
\text { kategoris, } \\
\text { presentase, } \\
\text { dan uji } \\
\text { statistik }\end{array}$ \\
\hline
\end{tabular}

\begin{tabular}{clr}
\hline c. & $\begin{array}{l}\text { Uji Coba } \\
\text { Luas }\end{array}$ & Tidak dilaksanakan \\
\cline { 1 - 1 } 3. & Pengujian & \\
\cline { 1 - 1 } 4. & Publikasi & Tidak dilaksanakan \\
\hline
\end{tabular}

Adapun saat penulisan artikel ini, tahap yang terlaksana masih sampai dengan uji validasi ahli materi dan ahli media pembelajaran.

\section{HASIL DAN PEMBAHASAN}

Proses pertama, yaitu melakukan studi pendahuluan diantaranya dengan studi pustaka dan survei lapangan. Hasil studi pendahuluan yang dilaksanakan kepada 4 guru di SD Negeri Dukuh o5 Salatiga dan siswa kelas 5 SD Negeri Dukuh 05 Salatiga. Berdasar hasil observasi yang telah dilaksanakan terhadap 4 guru di SD Negeri Dukuh o5 Salatiga diperoleh data sebagai berikut: 1) $75 \%$ guru menyusun rencana pelaksanaan pembelajaran secara tertulis sebelum pembelajaran Bahasa Jawa, 2) $100 \%$ guru telah menguasai materi pembelajaran yang akan dibelajarkan kepada siswa, 3) 100\% guru memberikan motivasi kepada siswa untuk konsentrasi mengikuti pembelajaran Bahasa Jawa, 4) 100\% guru memaksimalkan penggunaan buku teks pelajaran serta sumber-sumber yang lain terkait materi pembelajaran sebagai sumber bahan materi, 5) 100\% guru memberikan tugas kepada siswa secara terstruktur di dalam maupun di luar kelas, 6) 100\% guru memberi tanggapan berupa penghargaan/awards dan/atau 
sanksi/punishment kepada siswa dalam melaksanakan proses belajar, 7) 50\% guru mengoptimalkan penggunaan media pembelajaran, dan 8) $25 \%$ guru menggunakan media TIK sebagai sarana penyampaian materi pembelajaran Bahasa Jawa kepada siswa.

Kemudian, berdasarkan hasil observasi kepada siswa kelas 5 SD Negeri Dukuh o5 Salatiga diperoleh data sebagai berikut: 1) $100 \%$ siswa menyatakan bahwa telah menggunakan buku teks pelajaran dan sumber-sumber lainnya yang terkait materi pembelajaran sebagai sumber bahan materi, 2) 90\% siswa menanggapi tugastugas yang diberikan oleh guru secara terstruktur di dalam maupun di luar kelas, 3) $100 \%$ siswa mendapatkan tanggapan berupa penghargaan/awards dan/atau sanksi/punishment, 4) $75 \%$ siswa termotivasi untuk konsentrasi dalam mengikuti pembelajaran Bahasa Jawa, 5) 50\% siswa turut mengoptimalkan penggunaan media pembelajaran, dan 6) $20 \%$ siswa menggunakan media TIK sebagai sarana penyampaian materi pembelajaran Bahasa Jawa.

Berdasarkan kedua hasil studi pendahuluan, yaitu terhadap 4 guru dan siswa kelas 5 SD Negeri Dukuh 05 salatiga di atas maka pengembangan media pembelajaran AMBARAWA untuk meningkatkan hasil belajar bahasa Jawa siswa sekolah dasar dapat diatasi sehingga bukan hanya guru saja namun siswa dapat turut menikmati media TIK sebagai sarana penyampaian informasi dan pembelajaran. Penggunaan media TIK sebagai sarana atau alternatif guru dalam menyampaikan informasi kepada siswa. Siswa dapat memanfaatkan TIK sebagai fasilitas yang dapat membantu menumbuhkan keterampilan berpikir tingkat tinggi (HOTS) dalam pembelajaran Bahasa Jawa khususnya pada materi pecahan. Jadi, ketertarikan siswa terhadap TIK khususnya smartphone yang saat ini sangat besar dan seakan-akan menjadi ketergantungan yang mungkin dapat dikatakan sulit untuk dihindari, kini guru dapat turut mambantu mengarahkan dalam penggunaannya secara positif.

Media pembelajaran AMBARAWA ini merupakan media yang dikembangkan dengan menggunakan software Adobe Flash. Aplikasi yang dihasilkan bertipe .apk sehingga dapat di operasikan pada smartphone yang menggunakan Operating System Android seperti yang dikemukakan oleh Sholecul Aziz (2012: 5), Android adalah sistem operasi untuk smartphone layar sentuh seperti iOS Iphone dan OS Windows. Dalam penelitian yang berjudul "Pengembangan Media Pembelajaran IPA Berbasis Android untuk Siswa SD/MI" yang dilaksanakan oleh Prasetyo (2017: 121), dinyatakan bahwa memiliki kelayakan media pembelajaran dengan kategori sangat baik, memperoleh presentase sebesar $86,23 \%$ serta dengan tanggapan siswa sebesar 88,23\%. Maka, media pembelajaran berbasis Android dapat digunakan dalam kegiatan pembelajaran.

Proses kedua, melakukan penyusunan draf produk awal sebagai bentuk tanggapan terhadap hasil studi pendahuluan. Adapun dimulai dengan menentukan Kompetensi Dasar (KD), Rencana Pelaksanaan Pembelajaran (RPP) kelas 5 yang memuat pembelajaran Bahasa Jawa, terkhusus Aksara Jawa, dan membuat rancangan media pembelajaran AMBARAWA.

Proses ketiga, yaitu melaksanakan tahapan pengembangan produk media pembelajaran AMBARAWA. Produk 
media pembelajaran AMBARAWA yang telah dikembangkan untuk kemudian divalidasi oleh ahli materi dan ahli media. Oleh masukan dari kedua ahli tersebut, dilaksanakan revisi produk media pembelajaran AMBARAWA. Proses revisi dilaksanakan sehingga tampak perbedaan yang lebih baik serta sesuai dengan saran dan masukan ahli materi maupun ahli media. Produk media pembelajaran AMBARAWA sudah siap diuji coba melalui uji coba terbatas kepada siswa kelas 5 SD Negeri DUKUH o5 Salatiga. Seusai uji coba terbatas, proses pengembangan produk media pembelajaran AMBARAWA berarti dinyatakan telah selesai. Berikut ini adalah uraian hasil penelitian dan pengembangan produk media pembelajaran AMBARAWA.

Pelaksanaan pengembangan media pembelajaran AMBARAWA untuk meningkatkan hasil belajar bahasa Jawa siswa sekolah dasar dengan model ADDIE yaitu :

\section{Analysis}

Pada tahap ini telah dianalisis sesuai dengan hasil observasi yang tertuang pada bab sebelumnya, yaitu : a) pelaksanaan pembelajaran Aksara Jawa hanya 2 JP (Jam Pelajaran) atau setara 70 menit setiap minggunya, karena kurang dalam halnya alokasi waktu, sehingga tidak seluruh kompetensi tercapai dengan optimal dan maksimal. b) Media pembelajaran yang digunakan masih berupa tabel aksara Jawa dan Buku Pepak Basa Jawa. c) Kurangnya pemanfaatan TIK sebagai pendukung proses pembelajaran pada satuan pendidikan jenjang sekolah dasar. d) hasil belajar siswa dalam mata pelajaran Bahasa
Jawa terkhusus materi Aksara Jawa masih kurang. Dengan data di atas, maka telah diperoleh gambaran media pembelajaran yang akan dikembangkan.

\section{Design}

Pada tahapan ini dilakukan dengan merencanakan strategi pembelajaran yang akan dilaksanakan saat perlakuan (treatment), dan merumuskan konten/isi media pembelajaran yang akan diterapkan pada aplikasi ini. Sehingga hasil akhir dari tahapan desain ini adalah rancangan yang dapat menjawab permasalahan dari proses analisis sebelumnya. Desain media pembelajaran adalah tersedia sebagai berikut: tampilan awal AMBARAWA, tampilan petunjuk aplikasi, tampilan menu materi, tampilan menu materi aksara nglegena, tampilan kotak aksara nglegena, tampilan menu materi aksara pasangan, tampilan kotak aksara pasangan, tampilan menu materi aksara sandhangan, tampilan kotak aksara sandhangan, tampilan menu kuis, tampilan soal kuis, tampilan jika jawaban soal kuis "benar", tampilan jika jawaban soal kuis "salah", tampilan menu bantuan jawaban kuis, tampilan setelah menyelesaikan satu level, dan tampilan keluar dari aplikasi

\section{Development} adalah tahapan untuk merealisasikan secara benar dari tahapan desain yang telah dirancang sebelumnya. Pada tahapan ini meliputi penentuan metode pengembangan produk, serta pemilihan tools atau alat dan aplikasi pendukung yang 
akan digunakan dalam pembuatan aplikasi. Software yang digunakan dalam proses pengembangan ini adalah Adobe Flash dan/atau Adobe Animate. Hasil akhir dari tahapan ini adalah rancangan aplikasi yang nantinya akan dapat di implementasikan pada tahapan ADDIE selanjutnya, yaitu implement (penerapan).

4. Implement

Proses pada tahapan ini adalah merealisasikan seluruh perancangan yang telah dibuat pada tahapan sebelumya.

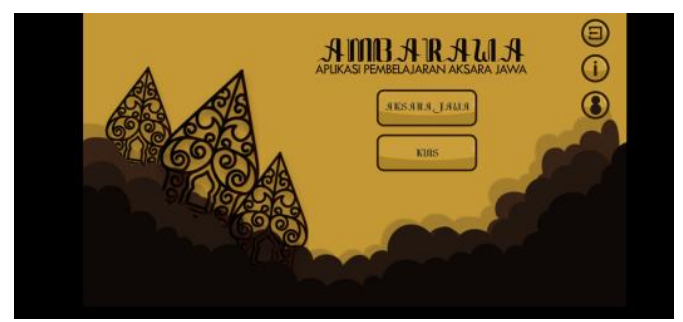

(a)

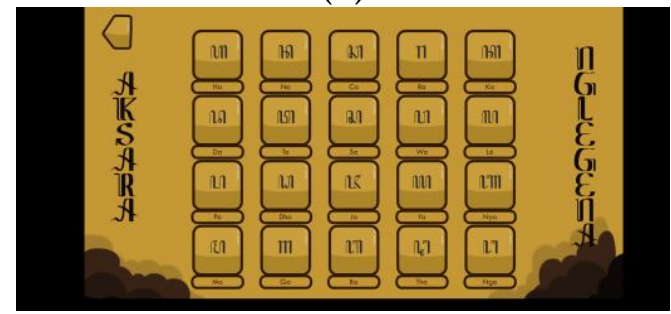

(c)

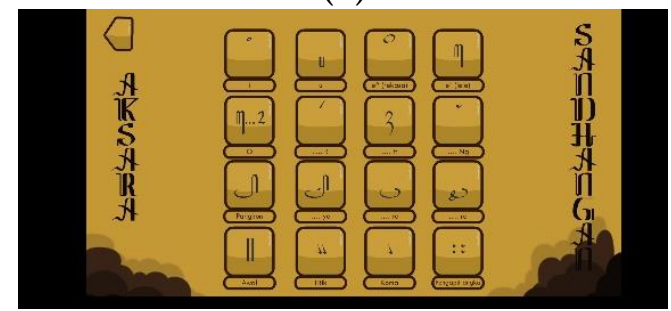

(e)

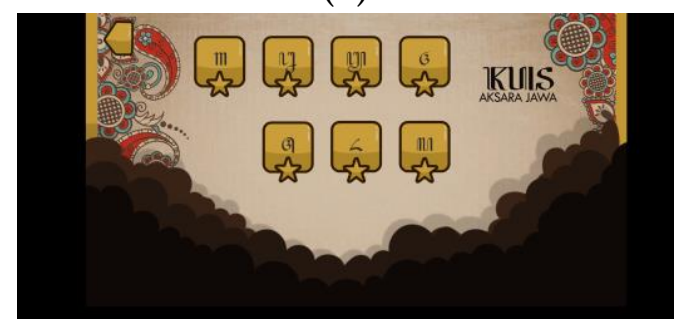

(g)
Sehingga dengan kata lain bahwa tahapan ini merupakan tahap membuat aplikasi menjadi bentuk aplikasi media pembelajaran yang sesungguhnya dengan menggunakan software Adobe Flash. Hasil akhir dari tahapan ini adalah aplikasi AMBARAWA.apk yang telah siap digunakan, namun masih ada beberapa tahapan sebelum di gunakan secara umum. Berikut tampilan dari AMBARAWA.apk pada Gambar 1:

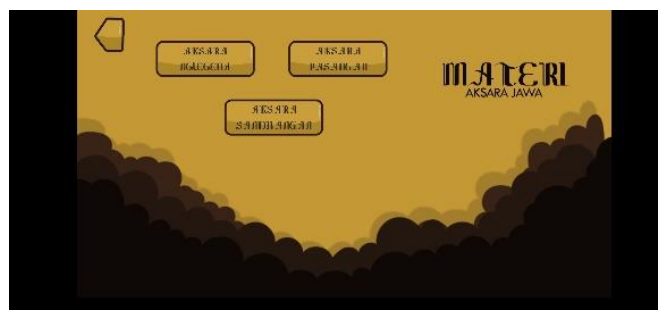

(b)

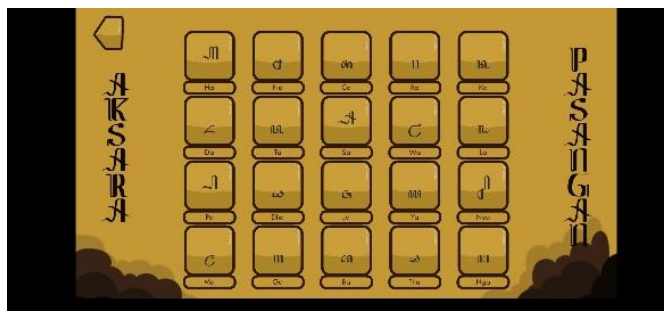

(d)

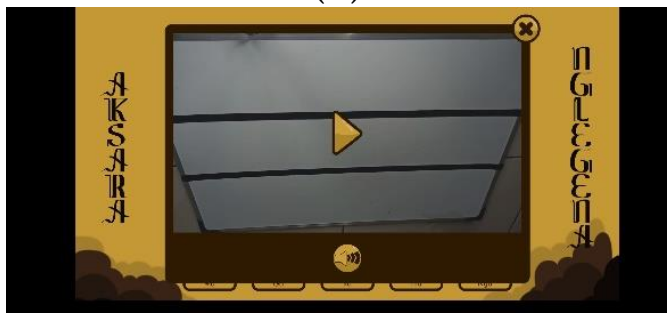

(f)

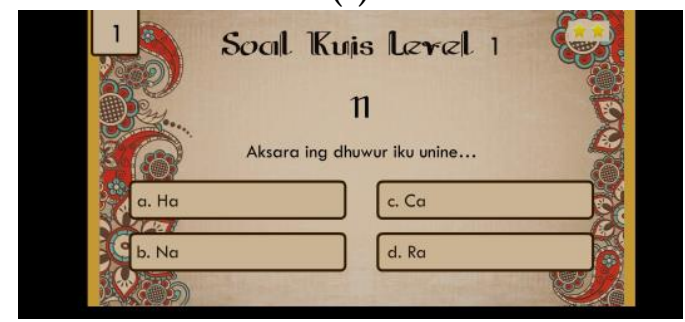

(h) 


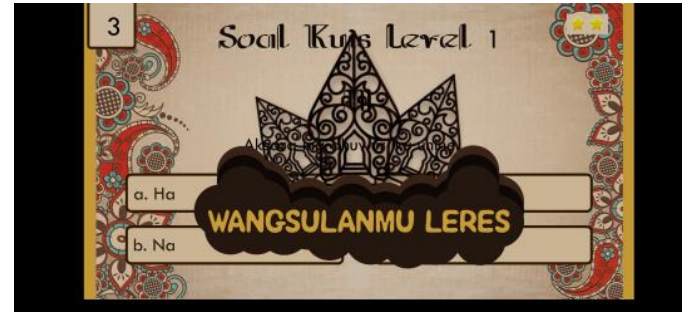

(i)

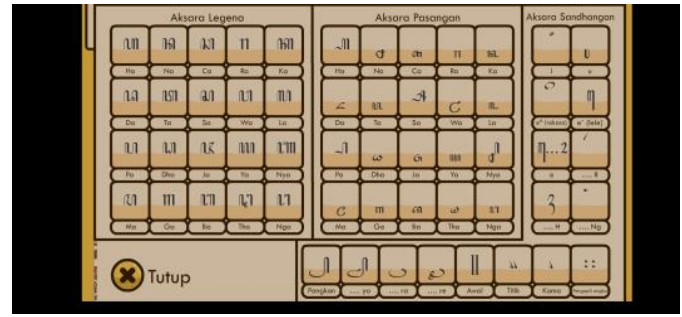

(k)

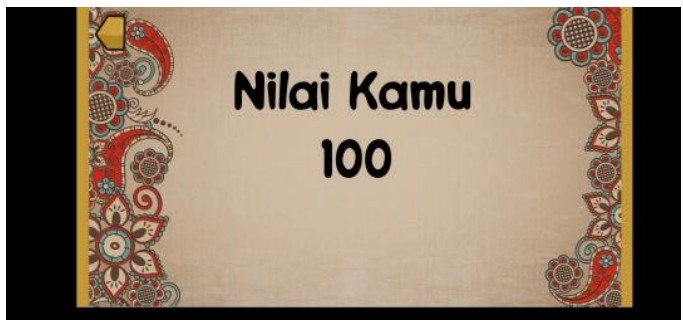

$(\mathrm{m})$

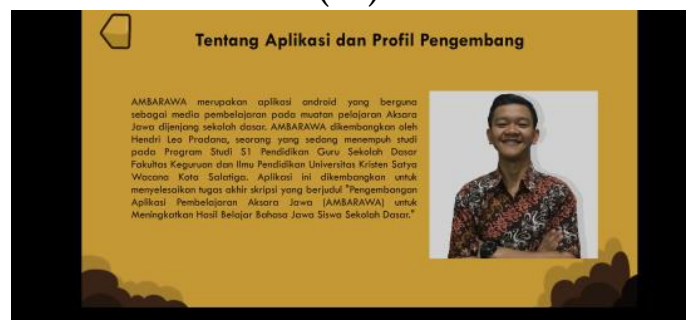

(o)

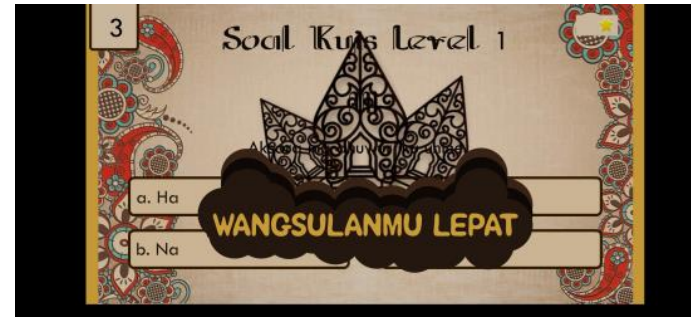

$(\mathrm{j})$

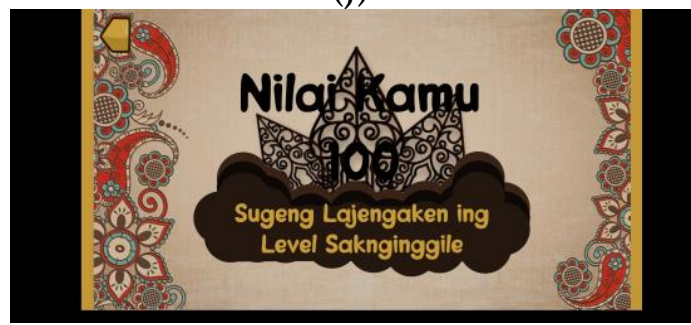

(l)

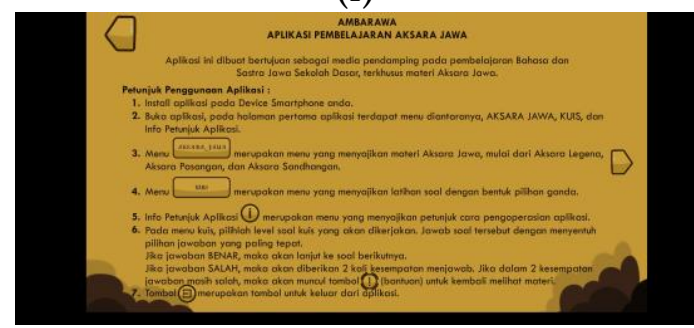

(n)

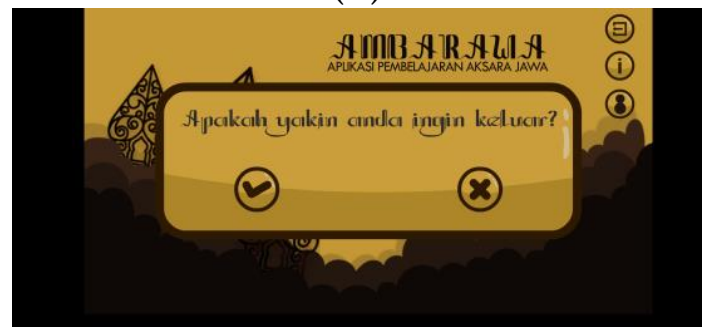

(p)

Gambar 1. Tampilan Media Pembelajaran AMBARAWA: (a) tampilan awal AMBARAWA, (b) tampilan menu materi, (c) tampilan menu materi aksara nglegena, (d) tampilan menu materi aksara pasangan, (e) tampilan menu materi aksara sandhangan, (f) tampilan kotak aksara (g) tampilan menu kuis, (h) tampilan soal kuis, (i) tampilan jika jawaban soal kuis "benar", (j) tampilan jika jawaban soal kuis "salah", (k) tampilan menu bantuan jawaban kuis, (l) tampilan setelah menyelesaikan satu level, (m) tampilan skoring, (n) tampilan petunjuk aplikasi, (o) tampilan tentang aplikasi dan profil pengembang, dan

(p) tampilan keluar dari aplikasi

\section{Evaluate}

Tahapan evaluasi dilakukan setiap proses pengembangan yang ada dalam model ADDIE. Evaluasi diberikan untuk menghasilkan aplikasi media pembelajaran yang layak melalui uji validasi ahli maupun rangkaian uji coba yang lainnya.
Setelah draft produk dikembangkan tahap selanjutnya adalah menguji produk oleh ahli materi pembelajaran dan ahli media pembelajaran. Para ahli tersebut adalah Dosen Fakultas Keguruan dan Ilmu Pendidikan Universitas Kristen Satya Wacana Salatiga. Hasil dari validasi ahli materi 
memperoleh skor 44 dengan persentase $88 \%$, termasuk dalam kategori sangat tinggi karena tergolong dalam interval 81-100\%. Hasil dari validasi ahli media pembelajaran memperoleh skor 45 dengan persentase $90 \%$, juga termasuk dalam kategori sangat tinggi karena tergolong dalam interval 81-100\%. Menurut Mawardi (2014: 113), hasil uji validasi media pembelajaran AMBARAWA dapat dikatakan layak untuk diujicobakan apabila presentase minimal mencapai kategori tinggi atau pada interval $61 \%-100 \%$.

Ada beberapa masukan dan saran dari validasi ahli, saran yang diberikan oleh ahli materi yaitu: 1) Teknik menulis aksara jawa : (1) menulis dengan lebih cepat, (2) Menulis dengan satu tarikan pena (tidak terputus-putus), (3) perhatikan tebal tipis penulisan aksara, (4) menulis dibawah garis tanpa cucuk.

2) Aksara Legena : yang benar Aksara Nglegena 3) Kuis : Sertakan poin untuk setiap level, kemudian dikalkulasikan ketika sudah menyelesaikan semua level. Poin persoal : Sekali jawab benar mendapat poin 20, dua kali menjawab baru benar mendapat poin 15, tiga kali menjawab baru benar (dengan tombol bantuan) mendapat poin 10 atau dalam kata lain mendapat poin -5 ketika salah menjawab. 4) Beberapa kunci jawaban dibetulkan. Serta saran dari ahli media yaitu 1) Tambahkan identitas pengembang AMBARAWA. 2) Gunakan text font yang lebih mudah untuk dibaca. 3) Berikan skema warna lain agar tidak monoton. 4) Tampilan media tulis menggunakan whiteboard atau chalkboard. Walaupun masih ada beberapa fitur yang perlu diperbaiki lagi, namun AMBARAWA mendapat kategori sangat tinggi menunjukkan bahwa media pembelajaran AMBARAWA layak digunakan.
Hasil penelitian yang berjudul "Media Pembelajaran Nyuwun Pirsa Untuk Meningkatkan Hasil Belajar Bahasa Jawa Siswa Setingkat Sekolah Dasar" yang ditulis oleh Syamsul Ma'arif dan Arif Setiawan (2020: 1) yang menghasilkan media pembelajaran aplikasi berbasis Android untuk meningkatkan hasil belajar Bahasa Jawa siswa sekolah dasar, hasilnya layak untuk digunakan karena memiliki kategori valid, praktis, dan efektif. Alasan ini menguatkan dasar dalam mengembangkan media pembelajaran Aplikasi Pembelajaran Aksara Jawa untuk meningkatkan hasil belajar Bahasa Jawa siswa sekolah dasar. Selain itu, didukung dengan Penelitian yang berjudul "Pengaruh Penggunaan Media Pembelajaran Berbasis Aplikasi Android Terhadap Hasil Belajar Siswa" yang ditulis oleh Rizki Suhendar Putra, Nanik Wijayati, dan Widhi Mahatmanti (2017: 2009). Dari hasil penelitian, didapat Ngain sebesar 0,71 untuk kelas eksperimen dan 0,54 untuk kelas kontrol menunjukkan hasil selisih yang besar. Selain itu, pengaruh signifikansi media pembelajaran berbasis Android terhadap hasil belajar siswa menunjukkan nilai o,77 dan koefisien determinasi sebesar 6o,16 dengan kategori signifikan. Dengan demikian, media pembelajara berbasis Android mampu meningkatkan hasil belajar siswa.

\section{SIMPULAN}

Berdasarkan hasil dari penelitian ini, simpulan yang diperoleh antara lain yaitu media pembelajaran berbasis Android AMBARAWA memperoleh hasil yang sangat valid setelah melalui proses pengujian oleh ahli materi pembelajaran dan ahli media pembelajaran. Hasil dari validasi ahli materi memperoleh skor persentase 88 
$\%$, termasuk dalam kategori sangat tinggi karena tergolong dalam interval 81-100\%. Hasil dari validasi ahli media pembelajaran memperoleh skor persentase $90 \%$, juga termasuk dalam kategori sangat tinggi karena tergolong dalam interval 81-100\%. Menurut Mawardi (2014: 113), hasil uji validasi media pembelajaran AMBARAWA dapat dikatakan layak untuk diujicobakan apabila presentase minimal mencapai kategori tinggi atau pada interval 61\% - 100\%. Artinya, Aplikasi Pembelajaran Aksara Jawa (AMBARAWA) layak digunakan sebagai media pembelajaran, khususnya pembelajaran Bahasa Jawa.

\section{DAFTAR PUSTAKA}

Abdillah, I., \& Sudrajat, D. (2014). Pengembangan permainan ular tangga pada pelajaran matematika untuk meningkatkan prestasi belajar siswa di SDN Majalengka Wetan VII. Jurnal Online ICTSTMIK IKMI, $11(1)$, 43-50.

Azis, S. (2012). Sekali Baca Langsung Inget: Mengupas Lengkap all about Android. Lembar Langit Indonesia.

Damayanti, R., \& Mawardi, M. (2018). Developing MITRA Learning Model of Problem SolvingBased to Solve Mathematical Problems in Elementary School. Jurnal Prima Edukasia, 6(1), 1-10.

Febrianti, F. U. A. (2018). Pengembangan Game Mobile Media Aksara Jawa Untuk Meningkatkan Hasil Belajar Bahasa Jawa. Joyful Learning Journal, 7(3), 8087.

Hallet,

https://www.weforum.org/agen $\mathrm{da} / 2016 / 11 /$ worlds-most- multilingual countries/, diakses pada 24 September 2020 pukul 18:29 WIB

Kusuma, Y. (2011). Membedah kehebatan Android. Jakarta: PT. Grasindo.

Ma'arif, S., Setiawan, A., Kom, S., \& Eng, M. (2020). Media Pembelajaran Nyuwun Pirsa untuk Meningkatkan Hasil Belajar Bahasa Jawa Siswa Setingkat Sekolah Dasar (Doctoral dissertation, Universitas Muhammadiyah Surakarta).

Mawardi, M. (2014). Model Desain Pembelajaran Konsep Dasar PKn Berbasis Belajar Mandiri Menggunakan Moodle. Kab. Semarang. Widya Sari Press.

Pembinaan, B. Pengembangan Bahasa, Kemendikbud. 2016. UndangUndang Republik Indonesia Nomor 24 Tahun 2009 Tentang Bendera, Bahasa dan Lambang Negara Serta Lagu Kebangsaan.

Pemerintah Daerah. 2012. Peraturan

Daerah Provinsi Jawa Tengah Nomor 9 Tahun 2012 tentang Bahasa, Sastra, dan Aksara Jawa. Sekretariat Daerah Jawa Tengah.

Gubernur Jawa Tengah. 2013. Peraturan

Gubernur Jawa Tengah Nomor

57 Tahun 2013 tentang Petunjuk Pelaksanaan Peraturan Daerah Provinsi Jawa Tengah Nomor 9 Tahun 2012 tentang Bahasa, Sastra, dan Aksara Jawa. Sekretariat Gubernur Jawa Tengah.

Prasetyo, S. (2017). Pengembangan Media Pembelajaran IPA Berbasis Android Untuk Siswa SD/MI. JMIE (Journal of Madrasah Ibtidaiyah Education), 1(1). 
Putra, R. S., Wijayati, N., \& Mahatmanti, F. W. (2017). Pengaruh penggunaan media pembelajaran berbasis aplikasi Android terhadap hasil belajar siswa. Jurnal Inovasi Pendidikan Kimia, 11(2).

Rahadi, D. R. (2014). Pengukuran usability sistem menggunakan use questionnaire pada aplikasi Android.JSI: Jurnal Sistem Informasi (E-Journal), 6(1).

Rohani, R. (2019). Media pembelajaran.

Sukmadinata, N. S. (2016). Metode Penelitian

Pendidikan. Bandung: Remaja Rosda Karya.

Undang-Undang Dasar Republik

Indonesia Tahun 1945 Pasal 36 